1997-2015 年における有明海全域の底質とマクロベントス群集の変化

\title{
Interannual variation from 1997 to 2015 in bottom sediments and community structures of macrobenthic fauna in the Ariake Sea, western Kyushu, Japan
}

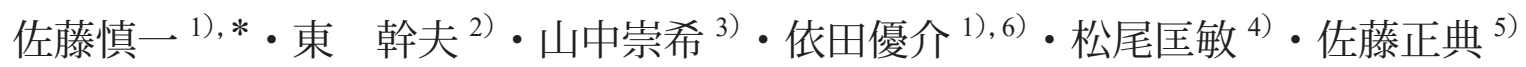 \\ 1) 静岡大学理学部地球科学科 $\bar{T} 422-8529$ 静岡市駿河区大谷 836 \\ 2) $\bar{T} 020-0556$ 岩手県岩手郡震石町名子 216-7 \\ 3）国土交通省 国土地理院７305-0811 茨城県つくば市北郷 1 \\ 4) 長崎県立宇久高等学校 T857-4901 長崎県佐世保市宇久町平 1042 \\ 5) 鹿児島大学大学院理工学研究科 $\overline{7} 890-0065$ 鹿児島市郡元 1-21-35 \\ 6) 現所属：株式会社八十二銀行 $\bar{T} 380-8682$ 長野市大字中御所字岡田 178 番地 8
}

Shin'ichi SATO ${ }^{1)}$ * , Mikio AZUMA ${ }^{2)}$, Takaki YAMANAKA ${ }^{3)}$, Yusuke YODA ${ }^{1), 6 \text {, }}$ Masatoshi MATSUO ${ }^{4)}$ and Masanori SATO $^{5)}$

1) Institute of Geosciences, Shizuoka University, 836 Ohya, Shizuoka 422-8529, Japan

2) 216-7 Nago, Shizukuishi-cho, Iwate 020-0556, Japan

3) Geospatial Information Authority of Japan, 1 Kitasato, Tsukuba 305-0811, Japan

4) Uku High School, 1042 Ukumachi-Taira, Sasebo, Nagasaki 857-4901, Japan

5) Graduate School of Science and Engineering, Kagoshima University, 1-21-35 Korimoto, Kagoshima 890-0065, Japan

6) Present address: The Hachijuni Bank, LTD., 178-8 Okada, Nagano 380-8682, Japan

\begin{abstract}
In order to evaluate the effect of $35.5 \mathrm{~km}^{2}$ of land reclamation in Isahaya Bay in the inner part of the Ariake Sea, Japan, we analyzed the interannual variation in the bottom sediments and community structures of macrobenthic fauna across the whole area of the Ariake Sea. Sediment samples were collected from 82 fixed subtidal stations consisting of four parts (inner, central-north, central-south, and mouth parts) in June 1997 (two months after the complete closure of the inner Isahaya Bay by the 7-km dike), June 2002 (two months after the temporary recovery of limited tidal currents within the inner Isahaya Bay by the opening of the water gates in the dike), June 2007, and June 2015. The median particle diameter of the bottom sediments decreased at many stations around the central to mouth parts of the Ariake Sea from 2002 to 2007, and it increased from 2007 to 2015 . A total of 29,885 macrobenthic invertebrates (mean density 7,289 ind. $/ \mathrm{m}^{2}$ ) were collected from the 82 fixed subtidal stations in June 1997, and the most dominant taxa were polychaetes, gammaridean amphipods, ophiuroids, and bivalves. In June 2002, 62,314 individuals (mean density 15,199 ind. $/ \mathrm{m}^{2}$ ) were collected from the same stations. However, the number and density of the macrobenthos declined to $11,992\left(2,925 \mathrm{ind} . / \mathrm{m}^{2}\right)$ in June 2007 and 17,669 $\left(4,310\right.$ ind. $\left./ \mathrm{m}^{2}\right)$ in June 2015. A similar pattern of the variation (i.e., an increase from 1997 to 2002, and a decrease from 2002 to 2007 and 2015) was commonly observed in the densities of each dominant taxon, and for all macrobenthos in each of the four parts of the Ariake Sea, although the variation was more remarkable in the inner and central-north parts than in the others. Our results suggest that the macrobenthic community has declined from 2002 to 2007 and 2015 not only around Isahaya Bay (in the inner part of the Ariake Sea), but across the whole area.
\end{abstract}

Key Words: Ariake Sea, bivalves, bottom sediments, gammaridean amphipods, macrobenthic fauna, polychaetes

\section{はじめに}

有明海の奥部西側に位置する諫早湾では，1997 年 4 月

Received 22 April 2020 Accepted 23 September 2020

* Corresponding author

E-mail: sato.shinichi.c@shizuoka.ac.jp
14 日に全長 $7,050 \mathrm{~m}$ の潮受け堤防により約 $35.5 \mathrm{~km}^{2}$ の浅 海域が閉め切られた（東 2000）。それ以降, 有明海全域に おいて環境とマクロベントス群集の顕著な変化が見られ （金澤ら 2005, 松尾ら 2007a,b, 上杉ら 2012, 折田ら 2019, 山中ら 2019), 現在でも漁船漁業やノリなどの養殖漁業が 深刻な不振に見舞われている。

有明海保全生態学研究グループ（代表：東 幹夫／森下 浩史）は, 1997 年 4 月の諫早湾潮受け堤防の閉め切り（潮 
止め) 以降に毎年実施している堤防内外の採泥調査に加え て，1997 年から 2015 年までの間に計 4 回（1997 年 6 月 ・ 2002 年 6 月・ 2007 年 6 月・ 2015 年 6 月), 有明海全域を 対象とした採泥調査を実施した（東ら 2018）。その結果, 1997 年から 2002 年にかけて, 有明海全域でマクロベント スの群集構造の変化が確認され (山中ら 2019), 特に湾奥 部と湾口部において特定種の急激な個体数密度の増加が見 られた（東 2000, 2005, 2011, 金澤ら 2005, 松尾ら 2007a,b, 上杉ら 2012, 東 - 佐藤 2016, 折田ら 2019, 山中ら 2019). しかし, その後の 2007 年には, 有明海全域で共通してマ クロベントスの個体数密度の急激な減少が確認された（上 杉ら 2012, 東・佐藤 2015, 2016, 東ら 2018, 折田ら 2019).

さらに, 毎年の有明海の奥部に限った採泥調査の結果か らは, 諫早湾の潮止め以降 1997 年から 2001 年まで堤防外 側海域のマクロベントスは減少傾向にあり, その後 2002 年 4-5 月に実施された短期開門調査直後の 2002 年 6 月に多 くの定点でマクロベントスの急激な増加が確認された（金 澤ら 2005). しかし, 短期開門終了後は急速にマクロベン トスが減少し, その傾向は 2003 年から 2018 年まで続いて いる（東ら 2018, 佐藤・東 2019）。有明海全域における 1997, 2002, 2007 年の 3 回分の調査結果は, これらマクロ心゙ ントスの変化が諫早湾潮受け堤防周辺に止まらず, 有明海 全域でも同様に進行していたことを意味している。しか し, 4 回目の 2015 年に実施された有明海全域調査の結果 については,これまで東ら（2018）が途中経過を報告した のみである.

マクロベントスは, 移動能力が低く動きが緩慢なため, 環境指標生物として優れた特性を持つ（菊池 1978）とと もに, 魚介類の重要な食物資源となっている（東・佐藤 2016, 首藤 2016). そのため, 最近のマクロベントスの消 長や動向は, 漁船漁業の現状把握や今後の予測にとって不 可欠な情報となる，本稿では，これまでの本研究グループ による調查結果を総括的に紹介し, 東ら（2018）が示した データを整理・修正することで, 1997 年から 2015 年まで の有明海全域における底質とマクロベントス群集全体の変 化や, 各動物群における優占種の分布変化を明らかにし た.また, 他研究のデータと比較することで, この期間で 特徵的な変化を示したマクロベントス種について論じた。

\section{諫早湾干拓事業をめぐる裁判の経緯}

諫早湾干拓事業をめぐっては, 現在もなお漁業者や営農 者などが原告となった複数の訴訟が裁判所で係争中である (堀 2019). 潮受け堤防閉め切り後, 2000 年 12 月から 2001 年初頭に空前のノリ不作を迎え, 2001 年 12 月に「有明海 ノリ不作等対策関係調查検討委員会」は, 諫早湾干拓事業 による有明海全域への影響を検証するため, 短期（2 ケ月 程度) - 中期 (半年程度) - 長期 (数年程度) の段階的開門 を実施することを提言した（東・佐藤 2015, 堀 2019). そ
の結果, 2002 年 4 月 24 日 5 月 20 日に短期開門が実施さ れ, 潮受け堤防内の淡水化された調整池内に潮位差 $0.2 \mathrm{~m}$ 以内の海水導入が行われた. 2004 年 8 月には, 佐賀地方裁 判所が諫早湾干拓事業の工事中止の仮処分を決定したが, その処分は 2005 年 5 月に福岡高等裁判所により取り消さ れ, 同年 8 月に最高裁判所も維持した（堀 2019）。これら の判決を受けて, 短期開門後に実施が予定されていた中・ 長期開門は実施されず，2007 年 11 月 20 日に干拓事業の 完工式が行われた。

しかし, 干拓事業完了後も有明海の異変と漁業不振は続 き, 2008 年 6 月に佐賀地方裁判所は開門判決を言い渡し, 2010 年 12 月に福岡高等裁判所も 1 審判決を維持した（堀 2019).これらの裁判では, 潮受け堤防内への海水導入 (農・漁・防災共存の段階的開門) の必要性が認められ, 2013 年 12 月までを準備期間とした上で， 5 年間の常時開 門が命じられ，国が上告を断念したことで確定判決となっ た。それにもかかわらず，2013 年 11 月に長崎地方裁判所 から開門差し止め仮処分判決が出されると, 国は 2010 年の 確定判決に対して異議請求を行うようになり，2018 年 7 月 に福岡高等裁判所が国の異議請求を認めた（堀 2019）。そ れに対して, 2019 年 9 月に最高裁判所は福岡高等裁判所の 判決を差し戻すとともに, 最高裁からの補足意見として, 2010 年の確定判決後の状況の変化を踏まえて審理するこ とを福岡高裁に対して要求した（佐藤ら 2020).

本研究グループは, 2010 年以降も現在まで有明海奥部 海域と全域において同一精度で継続的に調査を行なってお り, ここで得られたマクロベントスの生息状況の変化に関 する知見は, 今後の裁判所の適正な判断のためにも寄与す ることができると思われる。

\section{有明海全域で行われてきた採泥調査の概要}

有明海全域では，1997 年 6 月 3-5 日（92 定点）と 2002 年 6 月 5-6 日および 19-20日（88 定点）に長崎大学水産学 部の実習船「鶴水」, 2007 年 6 月 21-24 日（107 定点）と 2015 年 6 月 8-11 日（100 定点）に島原市の漁船「福好丸」 に乗船して採泥調査を実施した（Fig. 1, Table ES1 ; 折田ら 2019). 有明海全域において A1-92 までの 92 定点を設定し たが，2002 年は A23-24 と A33-34, 2015 年は A81-86 の採 泥調查をそれぞれ実施しなかったため, 本研究では過去 4 回すべてで共通する 82 定点（A1-22, 25-32, 35-80, 87-92） を集計の対象とした，各定点では, Smith-McIntyre 型採泥 器（採泥面積 $0.05 \mathrm{~m}^{2}$ ) により 1 回の採泥を行った. 得ら れた堆積物試料から粒度分析用試料として表層堆積物の一 部を取り除き，その他は船上で $1 \mathrm{~mm}$ 目の篩でろるい，篩 上に残ったすべてのマクロベントスを $10 \%$ ホルマリン海 水で固定して持ち帰った。 また，同時に各地点において多 成分水質計（アレック電子製 ADR-1000 など）を用いて表 層水と底層水の水温・塩分などを測定した。 


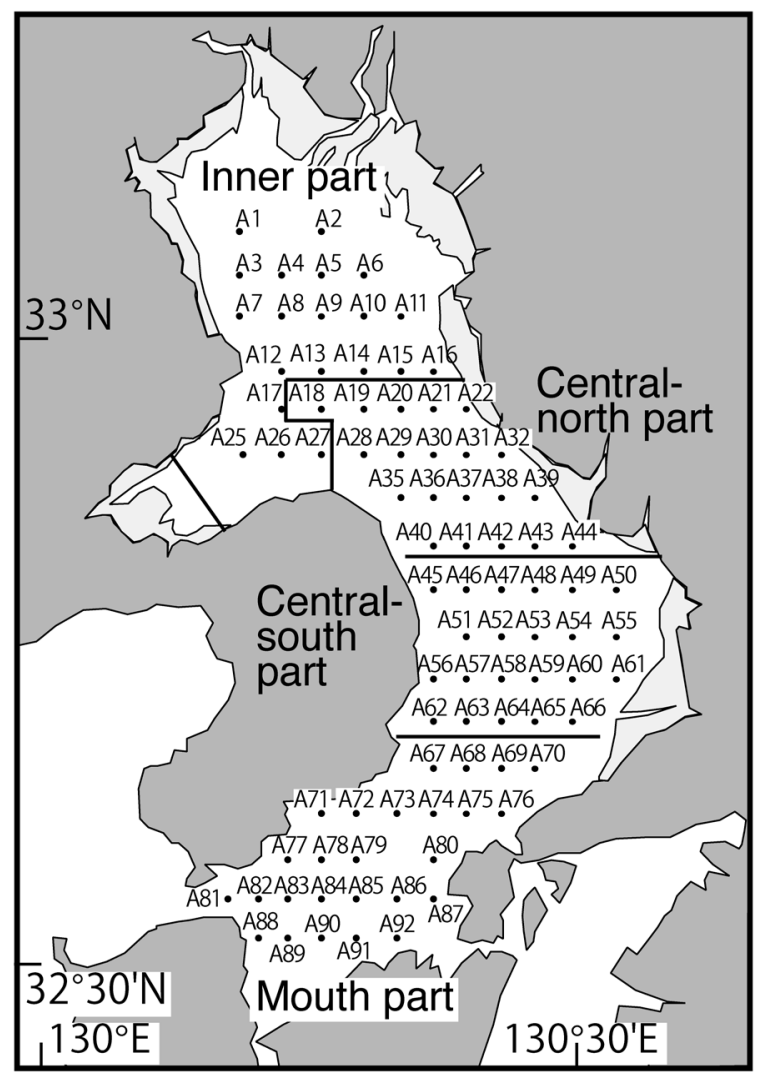

Fig. 1. Map showing the location of sampling stations in the Ariake Sea (data partly reproduced from Yamanaka et al. 2019).

その後, 室内で高次分類群レベルでの選別・計数を行 い, 二枚貝類については 1997, 2002, 2007, 2015 年の 4 回分 の全個体の種レベルの同定を行い, 種ごとの個体数を計数 した（金澤ら 2005, 上杉ら 2012, 依田 未発表データ)。多 毛類は 1997, 2002, 2007 年の 3 回分の 8 科 24 種の同定と計 数を行い（折田ら 2019）, ヨコエビ類は 1997, 2002 年の 2 回分の全個体の種同定と計数を行った（松尾ら 2007a,b). これらの同定・計数結果を基に, 高次分類群レ心゙ルの個体 数を修正した（Table ES 2). な押, 動物群の学名は, 既報 の文献（金澤ら 2005, 松尾ら 2007a,b, 折田ら 2019 など） に従った。

粒度分析は, 1997, 2002 年の試料は篩分法とピペット法 （近藤ら 2003）, 2007, 2015 年の試料は島津レーザ回折式 粒度分布測定装置（SALD-3100）を用いて, 中央粒径值 $(\mathrm{Md} \varphi)$ と含泥率などを求めた（上杉ら 2012）. 1997, 2002 年は採泥器で得られた堆積物に長さ $12 \mathrm{~cm}$, 内径 $2.6 \mathrm{~cm}$ の 塩化ビニールパイプを差し込んでコア試料を採取し（近藤 ら 2003, 松尾ら 2007a,b), 1997 年は表層から $12 \mathrm{~cm}$ まで, 2002 年は表層 2-3 cm までを対象とした粒度分析值を用い た（上杉ら 2012）。一方, 2007, 2015 年は表層約 $1 \mathrm{~cm}$ の堆 積物試料を粒度分析に用いた。 上杉ら（2012）は，2007年 に採集されたコア試料 10 定点分を用いて，近藤ら（2003） の手法で表層から $12 \mathrm{~cm}$ までを対象にして篩分法とピペッ
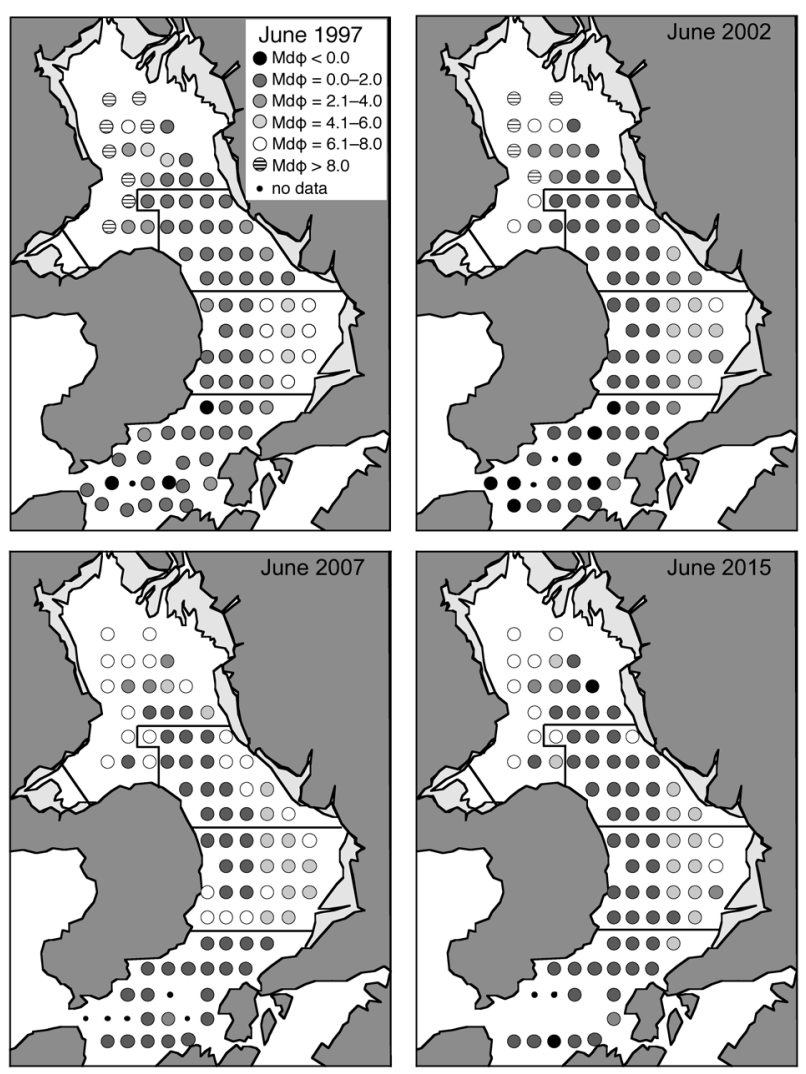

Fig. 2. Interannual variation in the median particle diameter $(\mathrm{Md} \varphi)$ of bottom sediments in the Ariake Sea from June 1997 to June 2015 (data partly reproduced from Orita et al. 2019). In the figure legend, "no data" means the particle diameter could not be measured because the sediment sample volume was too small. In June 2015, the sediment samples were not collected from the fixed stations of A81-86.

卜法で得られた $\mathrm{Md} \varphi$ 值と, 表層約 $1 \mathrm{~cm}$ の堆積物試料を対 象にしてレーザ回折式粒度分布測定装置による $\mathrm{Md} \varphi$ 值を 比較したところ，2つの粒度分析方法によるデータ間に有 意な差はないと判定された（Wilcoxon 符号順位検定：Z= $-1.019, \mathrm{p}=0.32$ ).

\section{有明海全域の底質粒度变化}

1997 年 6 月の有明海全域の底質は, 湾口部から湾央西 部の島原沖にかけては極粗粒〜中粒砂が分布し, 湾奥北東 部から島原半島国見沖に至る海域の定点は中粒砂〜シル ト，そして湾奥西部海域と諫早湾内および湾央東部の熊本 沖の定点ではシルト〜粘土の泥質堆積物であることが示さ れた（近藤ら 2003）。その傾向は, 2002 年 6 月・2007年 6 月・ 2015 年 6 月においても同様であり, 全体的な底質分 布は大きく変動していない（Fig. 2 ; 松尾ら 2007a,b, 上杉 ら 2012, 東ら 2018).

しかし, 海域ごとに見ると, 1997 年と 2002 年には $\operatorname{Md} \varphi$ $<0$ の極粗粒砂が有明海湾口部（A67, A73, A85, A88 など） に分布していたが，2007 年にはこれらの定点で $\operatorname{Md} \varphi>0$ 
となり，2015 年には湾口部の 1 定点（A90）と湾奥東部 （A11）で極粗粒砂が分布していた（Fig. 2)。さらに，2007 年に湾央北部の熊本県沿岸 (A22, 31, 32, 38) や湾央南部 の島原半島沿岸（A56, 62-64）などで底質の細粒化がみら れたが，2015年はA22を除けば 1997 年や 2002 年に近い 底質分布となった（東ら 2018）。

\section{マクロベントス群集の変化}

1997, 2002, 2007, 2015 年の 4 回実施した全域調査で共通 する 82 定点（Table ES2; A1-22, 25-32, 35-80, 87-92）にお いて, 最も多く採集された動物群は, 多毛類・ヨコエビ 類・二枚貝類・クモヒトデ類であった（Fig. 3)。また， 82 定点で採集されたマクロベントスの総個体数（平均個体数 密度）は，潮止直後の 1997 年 6 月の 29,885 個体（7,289 個体 $\left./ \mathrm{m}^{2}\right)$ から, 短期開門直後の 2002 年 6 月は 62,314 個体 (15,199 個体 $\left./ \mathrm{m}^{2}\right)$ に激增したが, 2007 年 6 月には 11,992 個 体 $\left(2,925\right.$ 個体 $\left./ \mathrm{m}^{2}\right)$ まで減少, そして 2015 年 6 月は局所 的なヨコエビ類の増加により 17,669 個体 (4,310 個体 $\left./ \mathrm{m}^{2}\right)$ となった（Fig. 3 ; 東ら 2018 を修正).

この傾向は, 諫早湾周辺のみならず, 有明海全域で共通 して見られる（Fig. 4 ; 東ら 2018). 有明海全域 82 定点を, 湾奥部 20 定点 (Fig. 1 の A1-17, 25-27), 湾央北部 20 定点 (A18-22, 28-32, 35-44), 湾央南部 22 定点 (A45-66), 湾 口部 20 定点（A67-80,87-92）に区分して，4回の採泥調 査で共通する 20-22 定点の海域で採集されたマクロベント スの平均個体数密度を比較すると, 4 海域とも同様に 1997 年に比べて 2002 年は急激に個体数密度が増加し, その後 2007 年に激減して 2015 年は微増または微減の傾向にあっ た（Fig. 4 ; 東ら 2018 を修正).

区分された 4 海域の平均個体数密度を比較すると, 1997

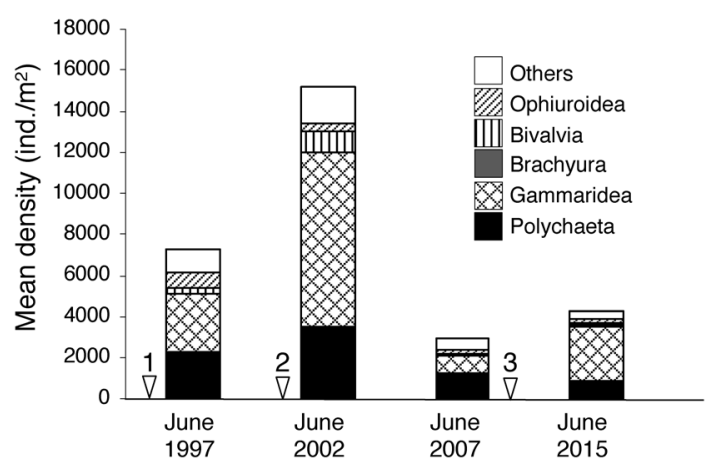

Fig. 3. Interannual variation in the mean density (ind. $/ \mathrm{m}^{2}$ ) of macrobenthic invertebrates collected from the 82 fixed subtidal stations in the Ariake Sea from June 1997 to June 2015 (data partly reproduced from Uesugi et al. 2012 and Azuma et al. 2018). White triangles indicate major events occurred around Isahaya Bay: (1) isolation by the reclamation dike on April 14, 1997; (2) the water gates of the reclamation dike were temporarily opened from April to May, 2002; and (3) the construction of the reclamation dike was completed on November 20, 2007 (Uesugi et al. 2012).
年の湾央北部と湾口部において, 他の海域よりもクモヒト デ類が複数の定点で多くの個体が採集されている（Fig. 4 ； 東ら 2018）。また， 2015 年には湾奥部（A13）と湾口部 （A91）においてヨコエビ類が 1 定点あたり 1,000 個体以上 も採集されたため, 他の海域に比べて採集されたマクロべ ントスの総個体数が増加した（Fig. 4). それに対して, 湾 央北部と湾央南部では, マクロベントスの採集個体数は 2007 年よりも 2015 年の方が少なかった.

有明海全域におけるマクロベントスの分布は, 1997 年は 湾奥南部 - 湾央北部と湾口部の海域で 500 個体 $/ 0.05 \mathrm{~m}^{2}$ 以 上の定点が多く, 湾奥北部（佐賀沖・諫早湾口）と湾央南 部東側（熊本沖）の海域で 100 個体 $/ 0.05 \mathrm{~m}^{2}$ 以下の定点が
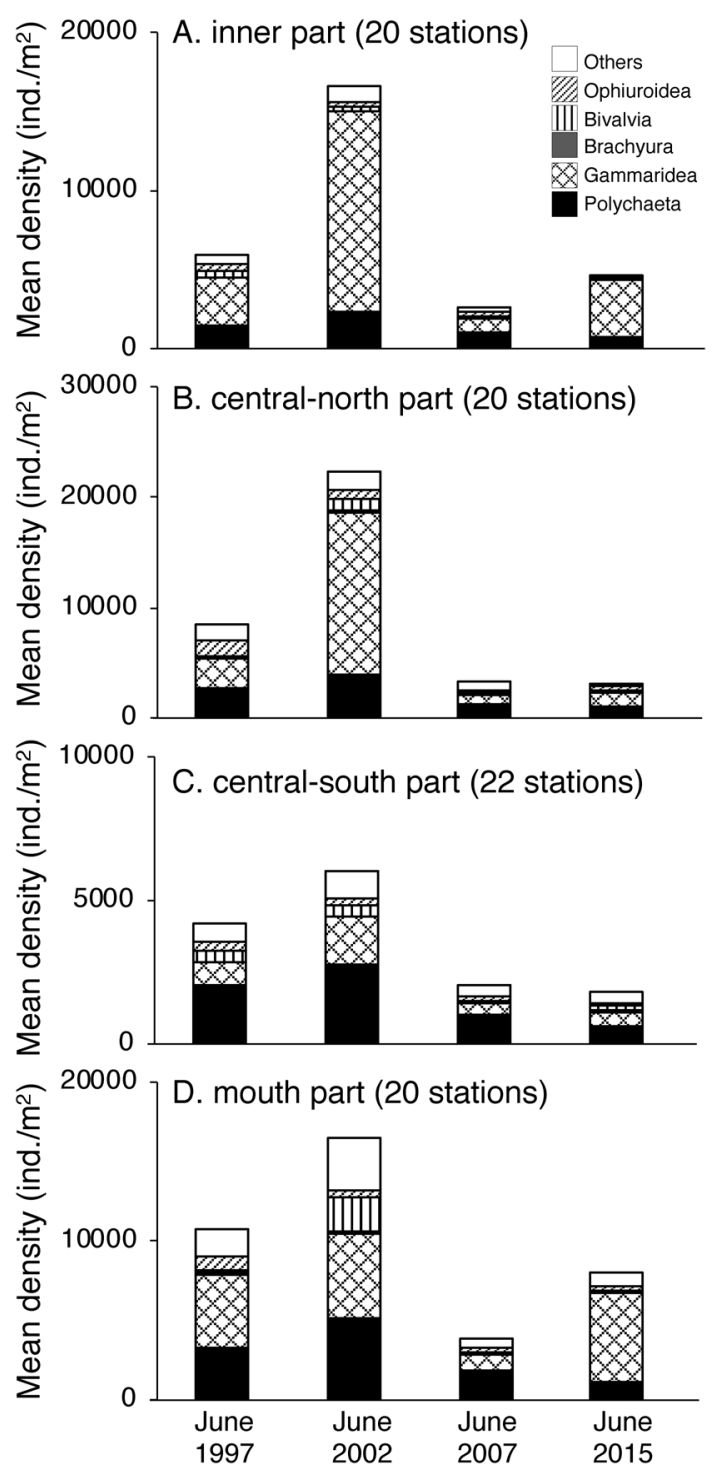

Fig. 4. Interannual variation in the mean density (ind. $/ \mathrm{m}^{2}$ ) of macrobenthic invertebrates collected from the inner part (A1-17, A25-27 in Fig. 1), central-north part (A18-22, A28-32, A35-44), central-south part (A45-66), and mouth part (A67-80, A87-92) in the Ariake Sea from June 1997 to June 2015 (data partly reproduced from Azuma et al. 2018). 
多く見られた（Fig. 5). 2002 年には湾奥南部と湾央北部 から湾央西側海域を経て湾口部までの広域に渡って 500 個 体 $/ 0.05 \mathrm{~m}^{2}$ 以上の定点が見られるようになり, 特に湾奥部 と湾央北部の 2 定点 $(\mathrm{A} 16, \mathrm{~A} 22)$ では 3,000 個体 $/ 0.05 \mathrm{~m}^{2}$ 以 上まで増加した。しかし, A 15 を除く全ての定点で 2007 年 には 500 個体 $/ 0.05 \mathrm{~m}^{2}$ 以下に減少し, 2015 年には A 13 と $\mathrm{A} 91$ で 1,000 個体 $/ 0.05 \mathrm{~m}^{2}$ 以上となったものの全体的には 2007 年と大きな違いは見られなかった (Fig. 5). 1997 年の 同一定点の採集個体数に比べて, 2002 年は湾奥部-湾央北 部と湾口部で 500 個体 $/ 0.05 \mathrm{~m}^{2}$ 以上増加した定点が多く, 2007 年と 2015 年はそれらの海域で 1997 年と比べて 500 個 体 $/ 0.05 \mathrm{~m}^{2}$ 以上減少した定点が見られた（Fig. ES1）.

\section{ヨコエビ類の分布変化}

マクロベントス全体のうち 4 回の採泥調査で有明海全域 の採集個体数が最も多かったヨコエビ類は, 1997 年は湾奥 部（A13）と湾口部（A89）の 2 定点で 1,000 個体 $/ 0.05 \mathrm{~m}^{2}$ 以上が採集され, 湾奥南部-湾央北部と湾口部の海域で 100 個体 $/ 0.05 \mathrm{~m}^{2}$ 以上の定点が多かった（Fig. 6). 2002 年は湾 奥部から湾央北部までの 10 定点 (A13-16, 20-22, 26, 28, 37) と湾口部の 1 定点 (A85) で 1,000 個体 $/ 0.05 \mathrm{~m}^{2}$ 以上が見ら れ, 100 個体 $/ 0.05 \mathrm{~m}^{2}$ 以上の定点は湾央北部から湾口部に かけての主に西側海域に連続的に分布した（Fig. 6). 1997 年に比べて, 2002 年にヨコエビ類の採集個体数が 500 個 体 $/ 0.05 \mathrm{~m}^{2}$ 以上も増加した定点は, 湾奥部一湾央北部の 14 定点と湾口部の 3 定点であった（Fig. ES2）.

しかし，2007 年は 1,000 個体 $/ 0.05 \mathrm{~m}^{2}$ 以上が採集された 定点はなく, 100 個体 $/ 0.05 \mathrm{~m}^{2}$ 以上が採集された定点も湾 奥部から湾口部までの 7 定点に減少した (Fig. 6). 2007 年 は, 1997 年と比べても多くの定点で採集個体数が減少して おり, 特に湾奥南部 - 湾央北部の 3 定点と湾口部の 2 定点 では採集個体数が 1997 年の同一定点に比べて 500 個体 / $0.05 \mathrm{~m}^{2}$ 以上も減少していた（Fig. ES2）. 2015 年は湾奥部 周辺と湾口部周辺のそれぞれ 8 定点で 100 個体 $/ 0.05 \mathrm{~m}^{2}$ 以 上が採集され，このうち諫早湾沖（A13）と三角沖（A91） の 2 定点では 1,000 個体 $/ 0.05 \mathrm{~m}^{2}$ 以上のヨコエビ類が採集 された（Fig. 6).しかし, 1997 年の同一定点の採集個体数 と比較すると, 特に湾央北部から湾口部までの多くの定点 で 2015 年の方が採集個体数は少なく, その傾向は 2007 年 と大きな違いは見られなかった（Fig. ES2）.

ヨコエビ類は, 1997 年と 2002 年の試料については全個 体の種同定が完了している（松尾ら 2007a, b). それらに よると, 有明海全域におけるヨコエビ群集の最優占種は, 1997 年はクダオソコエビ Photis longicaudata であり, 2002 年はドロクダムシ属の種 A Corophium sp. A であった（松尾 ら 2007a)。また, 1997 年から 2002 年にかけて, キタクダ オソコエビ Photis reinhardi とボウアシソコエビ Gammaropsis utinomii が湾奥南部の筑後川沖で増加したのに加えて, ド
ロクダムシ属の種 $\mathrm{A}$, トゲドロクダムシ C. crassicorne, ク ダオソコエビ, ニホンソコエビ Gammaropsis japonica, キ シドウヨコエビ Priscomilitaris tenuis が有明海湾央西部で 増加した（松尾ら 2007b）。このうち, ドロクダムシ属の 種 A とトゲドロクダムシは, 1997 年には有明海湾奥部と 湾口北部に分かれて分布していたが，2002 年に底質の粒 度組成変化に伴い有明海湾央西部から湾奥南部まで分布域 が広範囲に拡大したことが指摘された（山中ら 2019）。

\section{多毛類の分布変化}

有明海全域における多毛類の分布は, 1997 年は湾奥部か ら湾口部まで 30 個体 $/ 0.05 \mathrm{~m}^{2}$ 以上の定点が多く，そのうち 18 定点は 200 個体 $/ 0.05 \mathrm{~m}^{2}$ 以上であった（Fig. 7).2002 年 は湾奥部から湾口部まで 100 個体 $/ 0.05 \mathrm{~m}^{2}$ 以上の定点が増 加し, その中で 200 個体 $/ 0.05 \mathrm{~m}^{2}$ 以上の定点数は, 湾奥部 から湾央北部の 14 定点と湾央南部から湾口部の 19 定点に 増加した. 2002 年の採集個体数は, 1997 年の同一定点と 比較して, 100 個体 $/ 0.05 \mathrm{~m}^{2}$ 以上増加した定点が湾奥南部 - 湾央北部と湾口部の海域に多く見られた（Fig. ES3）.

しかし， 2007 年には 100 個体 $/ 0.05 \mathrm{~m}^{2}$ 以上の定点が 18 定点に減少し, 200 個体 $/ 0.05 \mathrm{~m}^{2}$ 以上の定点は湾奥部と湾 口部の 3 定点（A15, A71, A92）のみとなった（Fig. 7)。ま た, 1997 年の同一定点と比較しても, 湾央北部と諫早湾か ら湾口部までの 26 定点で 100 個体 $/ 0.05 \mathrm{~m}^{2}$ 以上も減少した のに対して, 100 個体 $/ 0.05 \mathrm{~m}^{2}$ 以上増加した定点は 2 定点 (A15, A92) のみであった（Fig. ES3）。さらに, 2015 年に は 200 個体 $/ 0.05 \mathrm{~m}^{2}$ 以上の定点はなく, 100 個体 $/ 0.05 \mathrm{~m}^{2}$ 以上を示す定点も湾奥部 2 定点（A11, A14）と湾口部 2 定 点（A89, A91）だけであり（Fig. 7)，1997 年の同一定点と 比べて 100 個体 $/ 0.05 \mathrm{~m}^{2}$ 以上増加した定点は見られなかっ た (Fig. ES3).

折田ら（2019）は, 1997 年から 2007 年までの 3 回分に ついて, 有明海全域の多毛類 8 科 24 種の分布变化を明ら かにした。 その結果, 有明海全域における多毛類 24 種の うち最も個体数が多かったのは, 1997 年と 2007 年は八ナ オカカギゴカイ Sigambra hanaokaiであり, 2002 年はチ口 リ Glycera nicobaricaであった。また, 多毛類 24 種を海域 別の出現状況に基づいて7つの分布パターンに分類した (I. 有明海全域：オノミチチロリ Glycera onomichiensis, チ ロリ, 八ナオカカギゴカイなど, II. 湾口部以外：カニゴカ イ Tambalagamia fauveli, III. 主に湾奥南部から湾口部まで: ニシキゴカイ Nereis zonata, トノサマゴカイ Scalibregma inflatum, IV. 湾奥南部, 中央部東部, 中央部西部 : ヒウチ ウミイサゴムシ Pectinaria hiuchiensis, V. 主に諫早湾, 最 奥部, 中央東部：フサウミダルマSternaspis costata, VI. 主に湾口部：キタチロリ G. capitata, エラナシチロリ $G$. tesselata, Pisione subulata，アリアケゴカイNicon japonicus, ウミケムシ Chloeia flava, VII. 出現地点数の少ない種; 折 

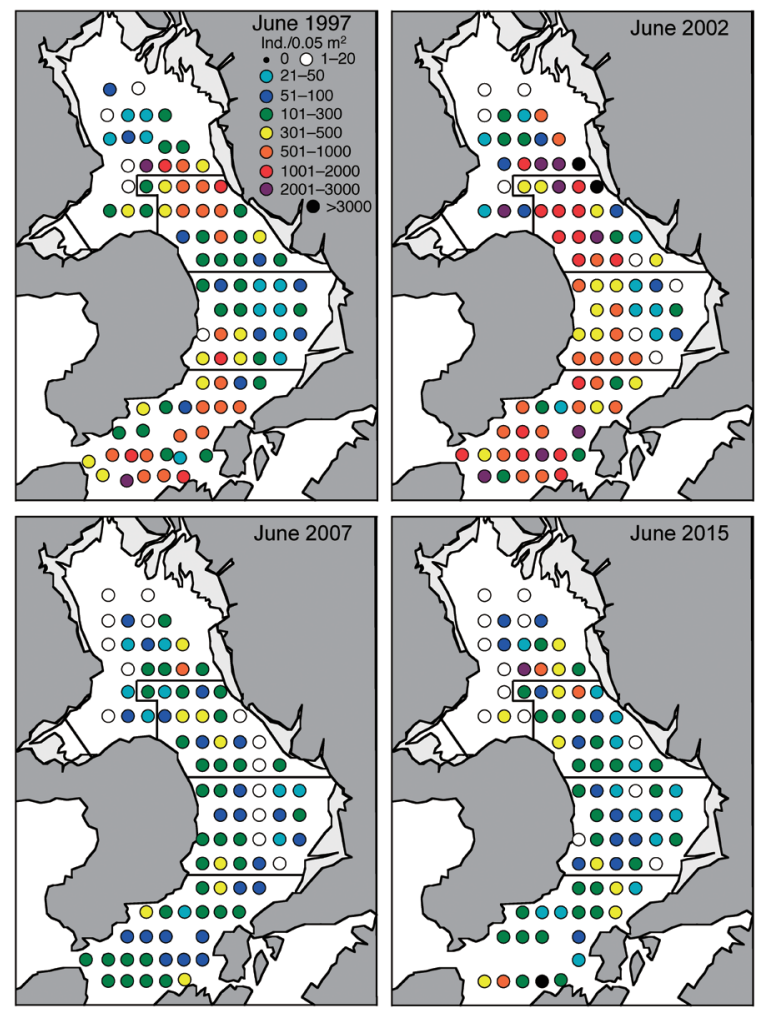

Fig. 5. Interannual variation in the density of macrobenthic invertebrates (ind. $/ 0.05 \mathrm{~m}^{2}$ ) in the Ariake Sea from June 1997 to June 2015.
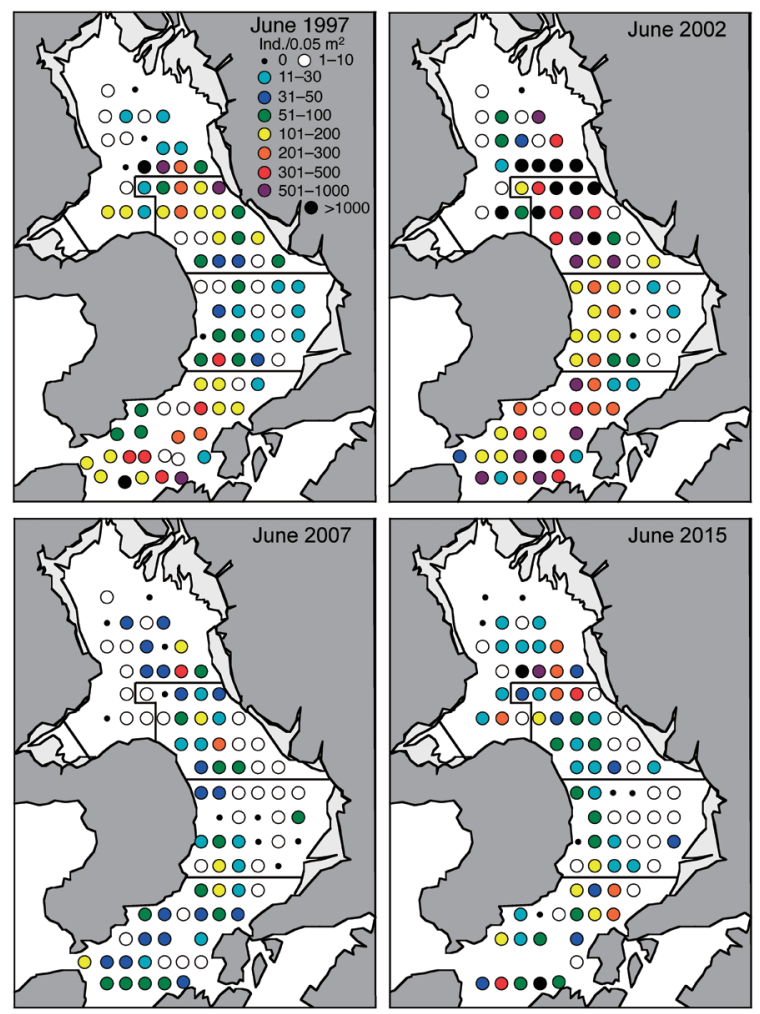

Fig. 6. Interannual variation in the density of gammaridean amphipods (ind. $/ 0.05 \mathrm{~m}^{2}$ ) in the Ariake Sea from June 1997 to June 2015 (data partly reproduced from Uesugi et al. 2012 and Azuma et al. 2018).
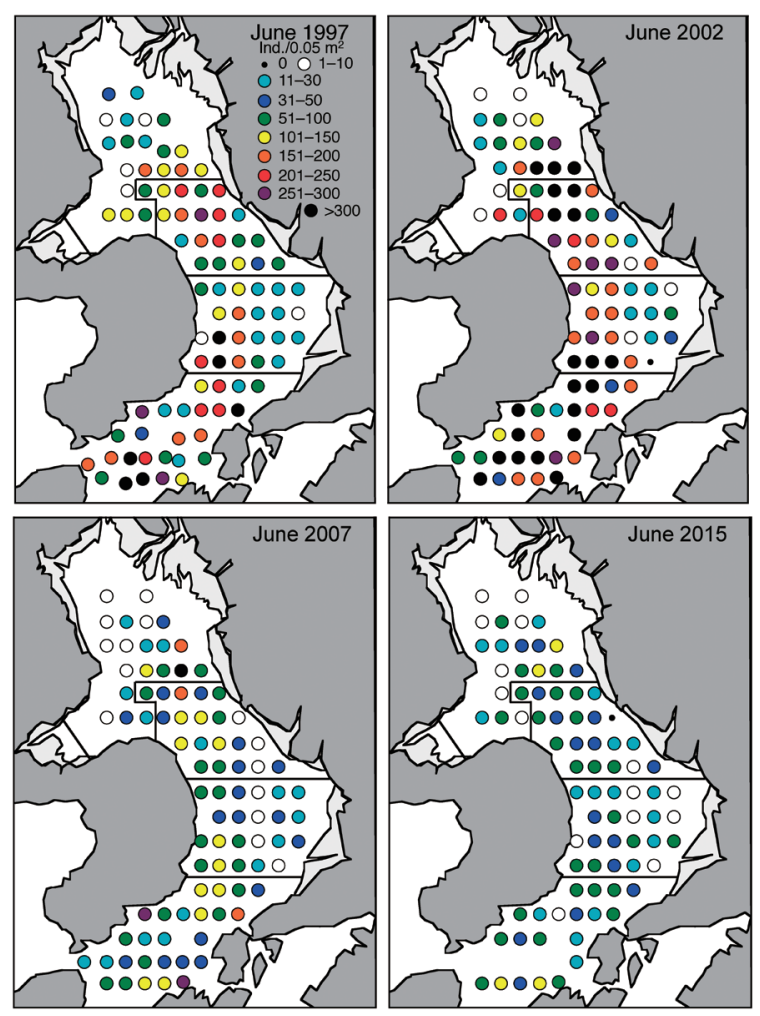

Fig. 7. Interannual variation in the density of polychaetes (ind./ $0.05 \mathrm{~m}^{2}$ ) in the Ariake Sea from June 1997 to June 2015 (data partly reproduced from Uesugi et al. 2012 and Azuma et al. 2018).
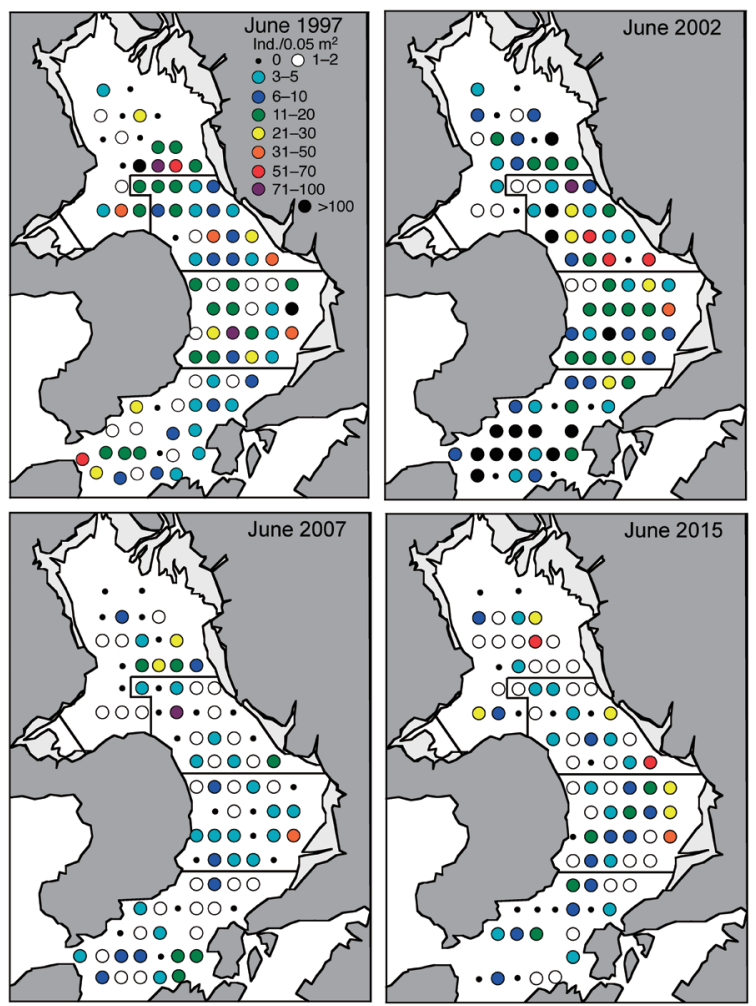

Fig. 8. Interannual variation in the density of bivalves (ind. $/ 0.05 \mathrm{~m}^{2}$ ) in the Ariake Sea from June 1997 to June 2015 (data partly reproduced from Uesugi et al. 2012 and Azuma et al. 2018). 
田ら 2019).

また, 1997, 2002, 2007 年における主な種の出現地点数 と平均個体数密度の増減を調べると, 上記のうち, チロ リ，カニゴカイ，フサウミダルマは 1997 年に比べて 2002 年に出現地点数が増加した後, 2007 年には出現地点数も 平均密度も減少した（折田ら 2019）。しかし，八ナオカカ ギゴカイのように出現地点数も平均密度もほとんど変化し ない種や，ウミイサゴムシのように 1997 年に比べて 2002 年に出現地点数が減少した後で再び 2007 年に出現地点数 と平均密度が増加した種もあり, 多毛類では種ごとに異な る分布パターン変化を示した。

\section{二枚貝類の分布変化}

二枚貝類は, 1997 年は湾奥部と熊本沖の 2 定点（A13, 55）で 100 個体 $/ 0.05 \mathrm{~m}^{2}$ 以上が採集され，2002 年は湾奥部 から湾央南部の 4 定点に加えて湾口部の 9 定点でも 100 個 体 $/ 0.05 \mathrm{~m}^{2}$ 以上が採集された（Fig. 8). 1997 年の同一定点 と比較して 2002 年に採集個体数が 100 個体 $/ 0.05 \mathrm{~m}^{2}$ 以上 増加した定点は湾奥部と湾央北部の 3 定点と湾口部の 8 定 点であったが， 100 個体 $/ 0.05 \mathrm{~m}^{2}$ 以上減少した定点は湾奥 部と熊本沖の 2 定点 (A13, A55) のみであった（Fig. ES4）.

しかし， 2007 年は 100 個体 $/ 0.05 \mathrm{~m}^{2}$ 以上の二枚貝類が採 集された定点はなく, 湾奥部から湾口部にかけての 10 定点 で 11 個体 $/ 0.05 \mathrm{~m}^{2}$ 以上が採集されただけであった（Fig. 7). 2015 年は諫早湾を含む湾奥部 3 定点と, 湾央北部から湾口 部までの 10 定点で 11 個体 $/ 0.05 \mathrm{~m}^{2}$ 以上を示した。ヨコエ ビ類と多毛類は湾央部では西側海域で比較的に個体数密度 が高かったが，二枚貝類では湾央部では西側よりも東側海 域で個体数密度が高いのが特徵である（Figs. 7-9）. 1997 年の同一定点と比較して 100 個体 $/ 0.05 \mathrm{~m}^{2}$ 以上増加した定 点は 2007,2015 年ともになく, 100 個体 $/ 0.05 \mathrm{~m}^{2}$ 以上減少 した定点はどちらも 2 定点であった (Fig. ES4). 2015 年の 有明海全域 82 地点における二枚貝類の採集個体数 (515 個 体）は，1997 年の同じ地点の採集個体数（1,257 個体）の 約 $41 \%$ であった. 2002 年の短期開門直後に二枚貝類の採 集個体数は 4,007 個体と急激に増加したが，2007 年には 407 個体にまで激減し, 2015 年の採集個体数は 2007 年と ほとんど差がなかった（Fig. 3).

二枚貝類に関しては, 1997, 2002, 2007, 2015 年の 4 回分 の全個体の種同定が完了した（金澤ら 2005, 上杉ら 2012, 依田 未発表データ). それによると, 有明海全域 82 定点 で採集された個体数が多かった種は, 1997 年はホトトギス ガイ Musculista senhousia とヤマホトトギスガイ Musculus japonica, 2002 年はキヌマトイガイ Hiatella orientalis とビ ロードマクラガイ Modiolus comptus, 2007 年はビロードマ クラガイとホトトギスガイ, 2015 年はシズクガイ Theora lubrica とヤマホホトギスガイであった.

1997, 2002, 2007, 2015 年の 4 回の有明海全域の分布パ
ターンで特徴的な変化が見られた種は，ビロードマクラガ イ, タマエガイ Musculus cupreus, キヌマトイガイであり, これらの種は 1997 年に比べて 2002 年に湾央北部と湾口 部で 100 個体 $/ 0.05 \mathrm{~m}^{2}$ 以上と多くの個体が採集されたが, 2007 年に定点 A29 でビロードマクラガイが 95 個体採集さ れた以外は 2015 年の全定点も含めて多くても 1-11 個体 / $0.05 \mathrm{~m}^{2}$ 程度しか採集されなかった（依田未発表データ）. これらの種に共通する特徴は, 足糸を出して碟などに接着 することであり，キヌマトイガイに関しては 2002 年に $\operatorname{Md} \varphi<0$ の極粗粒砂の定点で多く見られたが，2007 年には 極粗粒砂の定点が検出されず礫も少なかったため, 本種が 減少したことが指摘されている（上杉ら 2012）.しかし 2015 年には, 湾奥部（A11）と湾口部（A91）の 2 定点で 極粗粒砂が認められたものの, これらの定点では二枚貝類 はチヨノハナガイ Raetellops pulchellus とビロードマクラガ

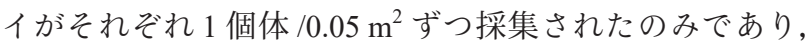
キヌマトイガイは採集されなかった（依田 未発表データ）.

\section{ヨコエビ類・多毛類・二枚貝類の 群集構造変化}

山中ら（2019）は，1997年 6 月と 2002 年 6 月に有明海 全域で採集されたヨコエビ類・多毛類・二枚貝類の同定・ 計数データを統合して，マクロベントス群集のクラスター 解析によるグループ区分と，それらの群集構造に影響を与 える環境因子の考察を行った。 その結果, 有明海全域のマ クロベントス群集は 7 つグループに区分された（I. シズ クガイ・ハナオカカギゴカイ・クビナガスガメ Ampelisca brevicornis など, II. ドロヨコエビ Nippopisella nagatai ・八 ナオカカギゴカイ・シズクガイ・チヨノハナガイなど, III. フサウミダルマ・ハナオカカギゴカイ・クビナガスガ メなど，IV. スンナリヨコエビ Maera serratipalma・キヌ マトイガイ・タマエガイなど, V. フクロスガメ Ampelisca naikaiensis・コブスガメ A. bocki など, VI. キタクダオソコ エビ・ボウアシソコエビ・ドロクダムシ属の種 A・ビロー ドマクラガイなど, VII. キタクダオソコエビ・キシドウヨ コエビ・ヤマホトトギスガイなど).

このうち, グループ I-III は有明海湾奥部と湾央東部に 分布し, グループ IV は湾口部を中心に分布，そしてグルー プV-VII は湾奥部から湾央西部に見られた。これらのグ ループ間では, 特に堆積物の含泥率と中央粒径值に有意差 が見られることが多く, 有明海全域のマクロベントス群集 は主に底質の影響を受けた分布をしているとした。さら に, 1997 年と 2002 年の有明海全域の底質の変化に着目す ると，含泥率 0-1\%の定点が 1997 年に比べて 2002 年に湾 央西部に多く見られたことから，グループIVの次に含泥 率の低い定点に多く分布したグループ VI の種群が，1997 年に比べて 2002 年に湾奥部から湾央西部の海域に分布を 広げたと推測された（山中ら 2019）。 
2007 年と 2015 年に関しては，二枚貝類のみ全個体の同 定・計数が完了しているが，1997年と 2002 年に多く見ら れたヤマホトトギスガイとビロードマクラガイは, 2007 年 には有明海全域での採集個体数が大幅に減少し，その後の 2015 年にはヤマホトトギスガイは湾奥部から湾央北部に 見られ，ビロードマクラガイは湾央南部から湾口部に分布 域を変えて生息していることが確認された（依田未発表 データ).ヨコエビ類と多毛類でも同様に，2007 年に有明 海全域における採集個体数の大幅な減少が確認されてお り，その後の 2015 年にも採集個体数の明確な回復は見ら れていない (Figs. 6, 7).

\section{その他の動物群の分布変化}

上記の 3 動物群以外では, クモヒトデ類が 1997 年には 湾央北部 6 定点と湾口部 4 定点で 100 個体 $/ 0.05 \mathrm{~m}^{2}$ 以上が 採集されたのに対して, 湾奥部と湾央南部はそれぞれ 1 定 点で 100 個体 $/ 0.05 \mathrm{~m}^{2}$ 以上が採集された（Fig. 9). 1997 年 の有明海全域 82 定点における採集個体数は 3,050 個体であ り, ヨコエビ類と多毛類の次に多く採集された。しかし, 2002 年は湾口部と湾央北部の 2 定点 (A28, 92) で 100 個 体 $/ 0.05 \mathrm{~m}^{2}$ 以上（A92 は 100 個体 $/ 0.05 \mathrm{~m}^{2}$ ）が採集された のみで, 82 定点の合計は 1,627 個体と 1997 年に比べて約
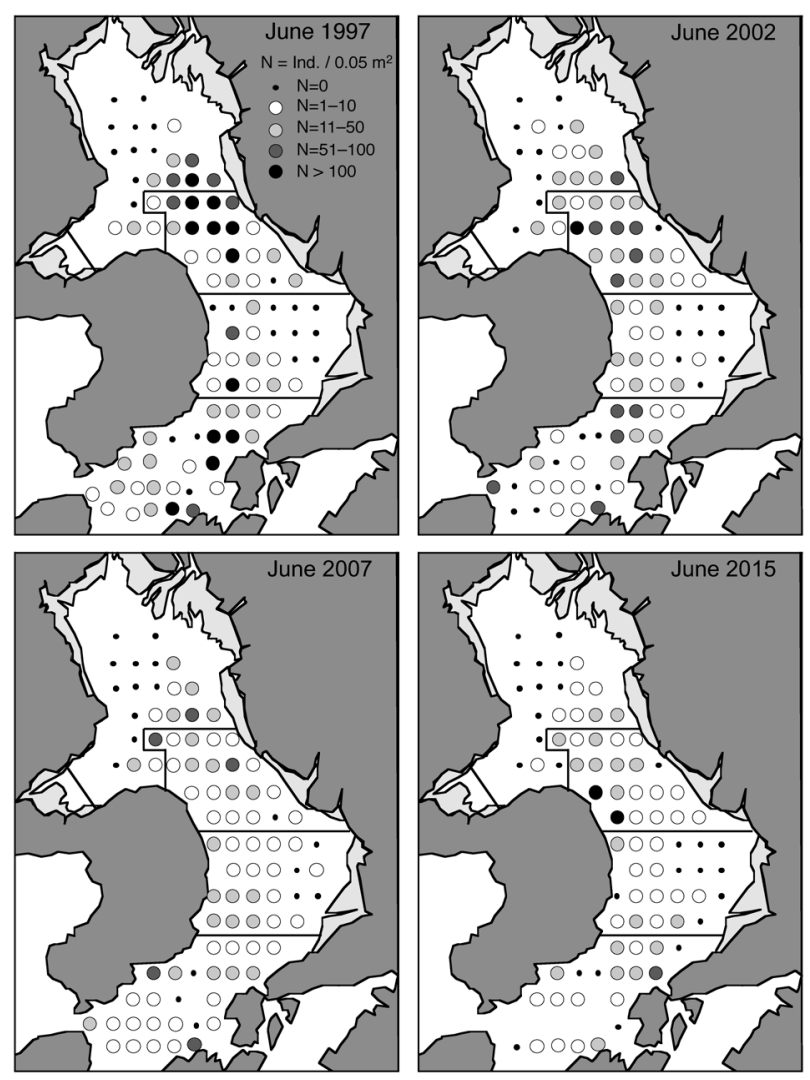

Fig. 9. Interannual variation in the density of ophiuroids (ind./0.05 $\mathrm{m}^{2}$ ) in the Ariake Sea from June 1997 to June 2015.
$53 \%$ まで減少した。 2007 年には 100 個体 $/ 0.05 \mathrm{~m}^{2}$ 以上の 定点はなく, 82 定点の合計も 920 個体と 2002 年よりさら に減少した。 2015 年には湾央北部の 2 定点（A35, 40）で 100 個体 $/ 0.05 \mathrm{~m}^{2}$ 以上を示したが，合計個体数は 926 個体 で 2007 年とほぼ同じであった.

また，頭索動物のヒガシナメクジウオ Branchiostoma japonicum は, 4 回の全域調査で共通して湾口部から湾央北 部までの範囲で複数個体が採集された（Fig. 10）. 1997 年 には湾口部から湾央北部までの 17 定点で採集され，特に 湾口部の 1 定点（A85）で 31 個体 $/ 0.05 \mathrm{~m}^{2}$ が採集された (Fig. 10). 2002 年は 15 定点で $1-9$ 個体 $/ 0.05 \mathrm{~m}^{2}$ が採集され たが，共通する 82 定点（A81-86 は対象外）での採集個体 数は 38 個体で, 1997 年の 41 個体より少なかった. 2007 年 は 8 定点で 1-3 個体 $/ 0.05 \mathrm{~m}^{2}$ が採集され, 82 定点での合計 は 12 個体とさらに減少した. 2015 年は 10 定点で 1-4 個 体 $/ 0.05 \mathrm{~m}^{2}$ が採集され, 82 定点での合計は 19 個体であり, 2007 年よりは多かったが 1997 年・2002 年の採集個体数に 比べると半数以下であった。

これらの動物群では, 1997 年が最も採集個体数が多く, 2002 年は 1997 年より減少している点で, ヨコエビ類・多 毛類・二枚貝類とは異なる変動を示している. クモヒトデ 類とヒガシナメクジウオは, どちらも湾口部が主要な分布 域であるのに対して，ヨコエビ類・多毛類・二枚貝類は湾
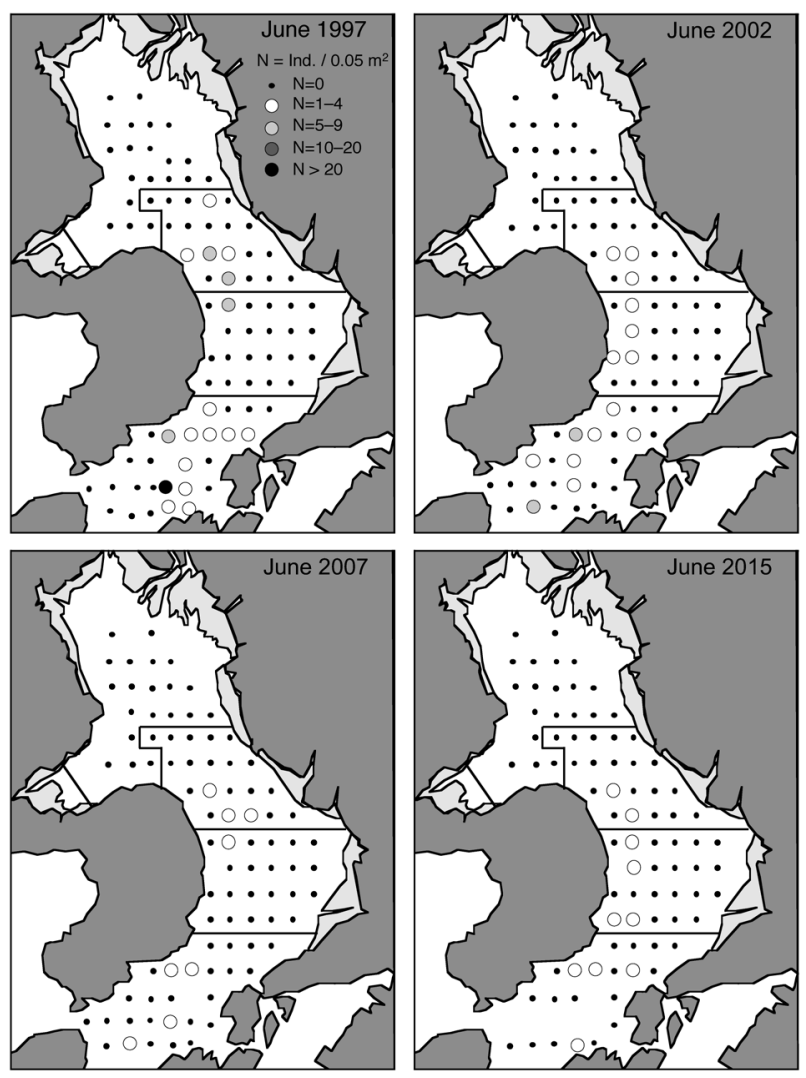

Fig. 10. Interannual variation in the density of Branchiostoma japonicum (ind. $/ 0.05 \mathrm{~m}^{2}$ ) in the Ariake Sea from June 1997 to June 2015 . 
口部に分布する種に加えて, 湾奥部と湾央北部に分布の中 心がある優占種も多く, それらが 2002 年に爆発的に増加 したことで, マクロベントス全体の分布変化に影響を及ぼ していることがわかる。しかし，すべての動物群で共通し て，2007 年と 2015 年の採集個体数は 1997 年と 2002 年に 比べて大幅に減少していた。

\section{他の研究とのデータの比較}

本研究グループ以外にも，1997-2015 年に有明海でマク ロベントスの調査を行なった研究例があり, そのうちの幾 つかは種レベルでの分布変化についても言及している（例 えば，大隈ら 2001, 陶山ら 2003, Yoshino et al. 2010, 2014, 園田ら 2013, 舆石ら 2015, Orita et al. 2015, Tsutsumi et al. 2015 など)。また, 1997 年以前のデータとして, 菊池 (1978) による 1972-1977 年の有明海全域調査や, 古賀（1991）に よる 1989 年の有明海湾奥調査などの結果が報告されてい る. そこで, 本研究とこれらの研究を比較検討した。

1972 年から 1977 年に有明海全域 21 地点を 5 回調査した 結果（菊池 1978）によると, 有明海湾奥部・諫早湾・熊 本県沿岸の泥質の地点では, 本研究と同じくシズクガイ・ チヨノハナガイなどの二枚貝類と, ドロクダムシ科端脚類 が多いことがわかる。しかし, イヨスダレ Paphia undulata・ ゴイサギ Macoma tokyoensis・イタボガキ Ostrea denselamellosa などの二枚貝類は, 本研究では貝殼はあっても生きた個体 がほとんど採集されておらず，当時の貝類相の豊富さがう かがえる. また, 種数と個体数密度の高い湾央北部の砂泥 質の地点と湾口部の砂礫質の地点では, 端脚類を主体とす る小型甲殼類が大半をなし，特に湾央北部の砂底ではタテ ソコエビ Stenothoe gallensis が優占種で, より泥質の地点 ではドロクダムシ属の種 Corophium sp. とホソヨコエビ Ericthonius pugnax が優占するとある (菊池 1978). 本研究 では, 1997 年・2002 年ともに, タテソコエビ属の採集個 体数は有明海全域でも合計 100 個体未満であり, 湾央北部 では 1 個体しか採集されなかった（松尾ら 2007a）。一方， ドロクダムシ属の複数種（ドロクダムシ属の種 $\mathrm{A}$, トゲド ロクダムシなど）とホソヨコエビは, 1997 年に比べて 2002 年に採集個体数が増加しており，これらの種が 1997 年以 前にも優占していたと推測できる。

1989 年 8 月の有明海湾奥 80 地点で採集されたマクロベ ントスは, 環形動物 68 種・軟体動物 59 種・節足動物 55 種・ 棘皮動物 11 種などで, 全体の種数の $88 \%$ を上位 3 門で占 めていた（古賀 1991）。二枚貝類では，ホトトギスガイ・ イヨスダレ・チヨノハナガイ・シズクガイ・ヒメカノコア サリVeremolpa micra の出現が多かったが，このうちイヨ スダレは本研究では貝殼は多いが生きた個体はほとんど採 集されず，湾奥部の貝類多様性の減少が確認された。また， ヒメカノコアサリは, 湾奥部で 2010-2011 年にかけ, 比較 的多く採集されたと報告されている（Yoshino et al. 2014）.
しかし，本研究による 1997, 2002, 2007, 2015 年の有明海全 域調査では合弁の貝殼は多かったが, 殼を開くと生きた個 体はほとんど確認されなかった。ヨコエビ類では湾奥部を 分布の中心とする種が少ないが, 1989 年の有明海湾奥 80 定点ではホソッツムシ Cerapus tubularis・クビナガスガメ・ スンナリヨコエビ・ドロヨコエビ・ホソヨコエビなどが多 く見られた（古賀 1991）。このうち，ホソッッムシ・クビ ナガスガメ・ドロヨコエビは, 1997 年と 2002 年でも泥底 に分布中心があった種にあげられているが，スンナリヨコ エビはむしろ湾口の粗粒砂の定点に多く見られ湾奥部では 採集されていない（松尾ら 2007a）。また，ホソヨコエビに ついても，1997 年には湾奥部ではほとんど採集されなかっ たが，2002 年には特に諫早湾口などで急激に増加した。 これらのことから，ヨコエビ類では有明海湾奥部の優占種 の一部が置き換わった可能性がある.

大隈ら（2001）は, 古賀（1991）と同一地点において, 2000 年 9 月に採泥調査を行い, 1989 年 8 月のデータと比 較したところ, 二枚貝類ではチヨノハナガイ・シズクガ イ・イヨスダレ・ヒメカノコアサリの減少とヤマホトトギ スガイの増加，そしてヨコエビ類ではホソッッムシ・クビ ナガスガメ・ドロヨコエビの減少とフクロスガメ・ホソヨ コエビ・ニッポンスガメ Byblis japonicus の増加を報告した. このうち, チヨノハナガイとシズクガイは年変動が激しく 1997 年以降も増減を繰り返しているが, 前述のようにイ ヨスダレとヒメカノコアサリは本研究で採集された個体数 は少なかった．ホソッッムシ・クビナガスガメ・ドロヨコ エビは, 松尾ら (2007a) でも 1997 年に比べて 2002 年に減 少したことが報告されている。しかし首藤ら（2020）によ るとエラホソッツムシ Cerapus erae が 1998 年 11 月から 2000 年 11 月までの間で連続して優占種 5 種に入っている ため, この時期に一時的に諫早湾口周辺で増加したと考え られる.フクロスガメ・ホソヨコエビ・ニッポンスガメは, すべて 1997 年に比べて 2002 年に有明海全域での採集個体 数が増加したが，これら 3 種は大隈ら（2001）の調査範囲 以南の海域で多く見られた（松尾ら 2007a）.

陶山ら（2003）と輿石ら（2015）は，2001 年 6 月及びそ の後 2003 年 10 月まで 5 回の採泥調査により, 湾口部を除 く有明海湾奥〜湾央南部海域 47 定点におけるマクロベン トスの主要種の分布変化を明らかにした。その結果，平均 生息密度が 100 個体 $/ \mathrm{m}^{2}$ 以上を示した種は，二枚貝類では アサリ・チヨノ八ナガイ・シズクガイ・ホトトギスガイ・ ビロードマクラガイ, ヨコエビ類ではドロクダムシ属の 1 種 Corophium sp. 1・タイリクドロクダムシ Corophium sinensis・ クダオソコエビ・ボウアシソコエビ，多毛類ではカザリゴ カイ Amphicteis gunneri・イトゴカイ科の 1 種 Mediomastus sp. 1 であり，2001-2003 年 6 月に採集された上位 5 種はア サリとシズクイガイ以外は毎年入れ替わったことを明らか にした。これらの種は，潮間帯に分布中心をもつアサリや タイリクドロクダムシを除けば，本研究のデータとほぼ同 
じ変動を示している．舆石ら（2015）が対象とした 20012003 年は, 2002 年 $4-5$ 月に実施された短期開門実施前後 の年にあたり, 本研究グループではデータのない 2002 年 11 月と 2003 年 6 月にも採泥調査を行なっているため, 今 後さらに詳細なデータの分析が期待される.

Tsutsumi et al. (2015) は，2002 年 4 月から 2008 年 11 月 まで 39 回にわたり, 有明海湾奥部 4 定点の採泥調査を実 施した。それによると，2002 年 4 月に $\operatorname{Stn} C$ （本研究では A14 に最も近い定点）において，アゴナガヨコエビ科の 1 種 Pontogeneiidae sp. が 5,175 個体 $/ \mathrm{m}^{2}$ の高密度で採集され ている. 本科の種は, 2002 年 6 月に同じ海域を調査した 松尾ら（2007a）と舆石ら（2015）のリストには見られず, 2002 年 4 月にのみ増殖したのか別種の誤同定なのか不明で ある. 二枚貝類に関しては, 2003 年 4 月にヤマホトトギス ガイが, 2003 年 8 月にビロードマクラガイが採集されてお り, 本研究による 2003 年 11 月の調査でも A 14 でヤマホト トギスガイが A 15 でビロードマクラガイが採集されてい ることに整合的である.

\section{ま と め}

有明海全域の底質分布は，1997 年から 2015 年まで大き な変化は見られなかったが, 熊本県沿岸や島原半島沿岸で 2007 年に広範囲の底質の細粒化が認められた他, 2015 年 には湾奥部で極粗粒砂の分布が確認されるなど，局所的な 底質変化がみられた（Fig. 2)。しかし，2015 年に極粗粒砂 が確認された 2 定点 $(\mathrm{A} 11,91)$ では，二枚貝類の増加は 見られなかった。 また，マクロベントスの採集個体数は, 1997 年に比べて 2002 年は 2 倍以上に増加したが, 2007 年 には 1997 年の $40 \%$ 程度にまで減少し, 2015 年でも 1997 年 に比べると $60 \%$ 以下の状態であり, 2015 年までに有明海全 域のマクロベントス群集の回復は見られなかった（Fig. 3). これは, ヨコエビ類・多毛類・二枚貝類などの主要な動物 群において, 2002 年にドロクダムシ属の種 A やビロード マクラガイなどの幾つかの日和見種が急激に増加したが, 2007 年にそれらがほぼ消滅するとともにそれ以外の 1997 年から残っていた種も減少し，その状況が 2015 年も続い ていることを意味している（Figs. 6-8）。2002 年に見られ たマクロベントスの採集個体数の急激な増加は, 有明海湾 奥部と湾央北部で特に顕著だが, 同時に湾央南部や湾口部 のように諫早湾潮受け堤防から遠く離れた海域でも見られ る (Figs. 4-5). 2002 年 4-5 月に実施された短期開門によ る影響が, 湾口部のマクロベントスの増加に及んでいるか どうかは, 今後に常時開門が実施されることでそのメカニ ズムを検証する必要がある，マクロベントスは，魚介類の 重要な食物資源である（東・佐藤 2016, 首藤 2016）ため, 有明海の漁船漁業の回復には, マクロベントス群集の回復 は必要不可欠である.しかし, 2007 年と 2015 年の有明海 全域におけるマクロベントスの採集個体数変化には, 1997
年と比べて回復傾向は認められないのか現実である.

謝 辞 : 長崎大学水産学部実習船「鶴水」の古川素直船長と乗 組員の方々, 漁船「福好丸」の松本正明船長, 長崎大学教育学部 の近藤寬名誉教授と元水産学部の西, 首英之氏, 鹿児島大学の市 川敏弘名誉教授, 長崎大学・鹿児島大学・東北大学・静岡大学の 卒業生の皆さんには，採泥調査において多大なご協力をいただいた。 これらの皆様に心より感謝申し上げます。本研究費の一部とし て, 佐藤慎一は JSPS 科研費 JP13740297, JP15740308, JP1965021, JP21500861, JP25440229, JP17K07564 と（財)水・クリ夕環境科学 振興財団助成金 (萌芽的研究), 高木仁三郎市民科学基金の研究 助成金を使用させていただいた。東は, 有明海保全生態学研究グ ループ代表として，(財)自然保護助成基金創立 10 周年記念助成 とプロ・ナトゥーラ・ファンド国内研究助成を使用させていただ いた．松尾は藤原ナチュラルヒストリー振興財団の助成金を使用 させていただいた。ここに記して感謝の意を表します。

Electronic supplementary material: The online version of this article (doi: 10.5179/benthos.75.54) contains supplementary material: Tables ES1 and ES2. Figs. ES1-ES4.

\section{引用文献}

東 幹夫 2000. 諫早湾干拓事業の影響. 佐藤正典 (編), 有明海 の生きものたち：干潟・河口域の生物多様性，海游舎，東京， pp. 320-337.

東 幹夫 2005. 底生動物相の経年変化. 日本海洋学会 (編), 有 明海の生態系再生をめざして, 恒星社厚生閣, 東京, pp. 118128.

東 幹夫 2011. 有明海異変と開門による再生 (その 2) 一底生動 物の経年変化から. 日本の科学者 46: 963-969.

東 幹夫 ・佐藤慎一 2015. 有明海の底生動物の長期定点調査から 見えてきたこと.日本の科学者 50: 65-69.

東 幹夫 ・佐藤慎一 2016. 諫早湾閉め切り以降の有明海底生動物 の消長. 諫早湾開門研究者会議 (編), 諫早湾の水門開放から有 明海の再生へ, 有明海漁民・市民ネットワーク，東京，pp. 8192.

東 幹夫 ・佐藤慎一 ・山中崇希 - 佐藤正典・松尾匡敏・市川敏弘 2018. 有明海再生までの底生動物の生産過程を生活環境と対比 して明らかにする採泥調査の継続. 自然保護助成基金助成成果 報告書 26: 1-10.

堀 良一 2019. 問われる司法と有明海再生. 田中 克 (編), い のち輝く有明海を：分断・対立を超えて協働の未来選択へ, 花 乱社, 福岡, pp. 218-237.

金澤 拓・佐藤慎一 ・東 幹夫 - 近藤 寛 - 西八首英之・松尾匡 敏 2005. 諫早湾潮止め後の有明海における二枚貝群集の変化. 日本ベントス学会誌 60: 30-42.

菊池泰二 1978. 内湾ベントス相に対する污染の影響. 堀部純男 (編), 環境科学としての海洋学 2 , 東京大学出版会, 東京, pp. 130-147.

古賀秀昭 1991. 有明海北西海域の底質及び底生生物. 佐賀県有明 水産試験場研究報告, 13: 57-79.

近藤 寛・東 幹夫・西ノ首英之 2003. 有明海における海底堆積 物の粒度分布と $\mathrm{CN}$ 組成. 長崎大学教育学部紀要一自然科学一 68: 1-14.

輿石裕一・清本節夫 - 西 潔 - 小菅丈治 - 田中徳子・陶山典子 ・ 鈴木健吾 2015. 2001 年から 2003 年の有明海奥部および中部海 域で採集されたマクロベントス一出現種および主要種の分 布一. 水産技術, 7: 113-138. 
松尾匡敏・首藤宏幸・東 幹夫 - 近藤 寛 -玉置昭夫 2007a. 有 明海潮下带の底質区分とヨコエビ群集一1997 年と 2002 年の比 較. 長崎大学水産学部研究報告 88: 1-42.

松尾匡敏・首藤宏幸 - 東 幹夫 - 近藤 寛 -玉置昭夫 2007b. 諫 早湾奥部締め切り後の有明海潮下帯ヨコエビ群集構造の変化. 日本ベントス学会誌 62: 17-33.

大隈 斉・江口泰蔵・川原逸朗・伊藤史郎 2001. 有明海湾奥部の 底質およびマクロベントス. 佐賀県有明水産振興センター研究 報告，20: 55-62.

Orita R., A. Umehara, T. Komorita, J. W. Choi, S. Montani, T. Komatsu and H. Tsutsumi 2015. Contribution of the development of the stratification of water to the expansion of dead zone: A sedimentological approach. Estuarine, Coastal and Shelf Science, 164: 204-216.

折田 亮・佐藤正典・佐藤慎一・近藤 寛・松尾匡敏・東 幹夫・ 山西良平・Yusof Shuaib Ibrahim ・松下 聖・下村真美 2019. 有 明海における多毛類 24 種の分布：1997 年・2002 年・2007 年の 調査に基づく 10 年間の変化. 日本ベントス学会誌 74: 43-63.

佐藤慎一・東 幹夫 2019. 諫早湾潮止め後 20 年間の有明海にお ける底生動物変化. 日本ベントス学会誌 73: 120-123.

佐藤慎一・折田 亮・山川彩子・阿部博和・松政正俊 2020. 特集 諫早湾閉め切りから 20 年, 有明海の現状と未来を考える (2). 日本ベントス学会誌 74: 98-99.

園田吉弘・滝川 清・川崎信二・青山千春・齊藤 孝 2013. 有明・ 八代海海域における海水温変動と底生生物群集の応答特性. 土 木学会論文集 B2 (海岸工学), 69: I_1116-I_1120.

首藤宏幸 2016. 沿岸成育場における多様な餌生物と稚魚による捕
食. 海洋と生物, 38: 675-680.

首藤宏幸・松尾匡敏・佐藤慎一・東 幹夫 2020. 諫早湾潮受け堤 防の締め切り後 5 年間の有明海中央部における底生端脚類群集 の変化. 日本ベントス学会誌 74: 100-108.

陶山典子・舆石裕一・須田有輔・村井武四 2003. 底質から見た有 明海北部の海域区分とマクロベントスの分布. 水産大学校研究 報告，51: 105-114.

Tsutsumi, H., A. Takamatsu, S. Nagata, R. Orita, A. Umehara, T. Komorita, S. Shibanuma, T. Takahashi, T. Komatsu and S. Montani 2015. Implications of changes in the benthic environment and decline of macrobenthic communities in the inner part of Ariake Bay in relation to seasonal hypoxia. Plankton and Benthos Research, 10: 187-201.

上杉 誠・佐藤慎一・佐藤正典・松尾匡敏・近藤 寛・東 幹夫 2012. 諫早湾潮止め後 10 年間の有明海における主な底生動物相 の変化. 日本ベントス学会誌 66: 82-92.

山中崇希・佐藤慎一・松尾匡敏・佐藤正典・東 幹夫 2019. 諫早 湾潮受け堤防閉切り後の有明海全域における水質 - 底質変化と 二枚貝類・ヨコエビ類・多毛類の群集構造変化. 日本ベントス 学会誌 74: 67-74.

Yoshino, K., T. Hamada, K. Yamamoto, Yamaguchi and K. Ohgushi 2010. Effects of hypoxia and organic enrichment on estuarine macrofauna in the inner part of Ariake Bay. Hydrobiologia, 652: 23-38.

Yoshino, K., T. Katano, Y. Ito, T. Hamada, N. Fujii and Y. Hayami 2014. Community assembly by limited recruitment in a hypoxia-stressed soft bottom: A case study of macrobenthos in Ariake Bay. Plankton and Benthos Research, 9: 57-66. 